\title{
'This place was made for pleasure not for death': Performativity, Language, and Action in The Spanish Tragedy
}

Using J.L. Austin's theory of performative language, which stands in peculiar relationship to the literary or the dramatic, this paper traces how language and action function together in specific contexts in Thomas Kyd's The Spanish Tragedy. This study seeks to answer why Kyd uses multiple languages in Hieronimo's playlet of Soliman and Perseda, and how those languages sever the connection between word and action. No gestures can make Soliman and Perseda intelligible to the audience or to the actors in the playlet; gestures that usually mean one thing in the theatre (pretending to kill) become devoid of meaning in this deadly play-withinthe-play. Hieronimo's tongue-biting following the performance serves to punctuate the disintegration of word and action and the inability of words to effect further action.

Thomas Kyd's The Spanish Tragedy was the third most performed play in the 1590s, following only the lost Wise Man of Westchester and Christopher Marlowe's The Jew of Malta. According to Emma Smith, Kyd's play tallied 29 performances in the 1590 s alone. ${ }^{1}$ It was equally popular in print: initially printed in 1592, The Spanish Tragedy was reprinted in quarto form in 1594 and 1599 and at least seven times between 1602 and 1633. Seeing and hearing the play in the playhouse and reading the play would have been different experiences, given the hangings, shootings, and stabbings that litter the stage with bodies. The play's popularity in both mediums, however, suggests that the early modern English playgoer found the play equally effective whether performed or read.

Critics too have found the play's spectacle and language captivating, despite the play's limited recent performance history. ${ }^{2}$ While more than a few studies focus on Kyd's language, a number also focus on the play's action

Alexandra Ferretti (amstewart2@crimson.ua.edu) is a doctoral student in the Hudson Strode Program in Renaissance Studies at the University of Alabama. 
and spectacle. ${ }^{3}$ In these readings, Hieronimo's deadly playlet of Soliman and Perseda is usually interpreted as a reenactment of the confused languages in the biblical story of the Tower of Babel. This interpretation originates from Balthazar's objection to Hieronimo's choice of multiple languages for the action: 'But this will be mere confusion, / And hardly shall we all be understood' (4.1.180-1). ${ }^{4}$ Like Babel, in which 'the Lord did confounde the language of all the earth' (Gen 11:9), ${ }^{5}$ Hieronimo 'confounds' the language of his actors, according to Arthur Freeman: 'like God and the builders of the Tower of Babel, he wreaks confusion with words, and with "unknown languages" puts an end to the unchastised misbehaviour of his enemies'. ${ }^{6}$ Eleanor Tweedie, Sheldon Zitner, Steven Justice, Richard Hillman, S.F. Johnson, and Peter Murray have also argued for this biblical interpretation. While my own reading of the playlet differs from this reading, these critics assume (as I do) that the playlet's preceding note indicates Soliman and Perseda was truly performed 'in sundry languages' in the playhouse: 'Gentlemen, this play of HIERONIMO in sundry languages, was thought good to be set down in English more largely, for the easier understanding to every public reader' (4.4.10 sd). ${ }^{7}$

In keeping with this tradition, William $\mathrm{N}$. West has recently argued that confusion, for both the royal court and the playhouse audience, is an essential result of the playlet. He argues, "It is hard to overstate the negative connotations of the word "confusion" in early modern England; it is virtually a synonym (along with "innovation") for ruin'. ${ }^{8}$ Like West, I believe that the audience's confusion is essential to the playlet, but not exclusively because confusion signals ruin for the early modern English audience. ${ }^{9}$ Instead, I contend that the audience's incomprehension reflects the fact that the playlet is no longer a conventional performance; in other words, the typical circumstances of a performance change. By examining the circumstances of earlier performative situations throughout The Spanish Tragedy, I will show that we can also anticipate this disintegration of language and action in the playlet. In the playlet itself, language is no longer united with action, and action itself loses its typical meaning (pretended or theatrical stabbing becomes actual deadly stabbing). ${ }^{10}$

A reading of the play based on the theory of performative language, in tandem with a reading of contexts in The Spanish Tragedy, yields a new understanding of Hieronimo's playlet of Soliman and Perseda. Reading The Spanish Tragedy through these lenses explains why the playlet is in multiple languages and what effect it achieves in Kyd's play (beyond the obvious effect of accomplishing Hieronimo's revenge). Theatregoers assume they 
will understand the action that transpires on the stage, even if the words are spoken in a different language (consider the French-language passages of Shakespeare's Henry $V$, for instance). When that convention falls apart when the performance is no longer comprehensible and the circumstances radically change (from theatre to reality) - then performative language can no longer effect action and the meaning of action itself becomes destabilized. Hieronimo, whose performative power as knight marshal is undermined by Lorenzo and Balthazar's hanging of Horatio in his bower, destroys the King's performative power as sovereign to mete out justice in the royal court. Through his staged revenge, Hieronimo signifies the annihilation of language and action's meaning through the altered conventions, or circumstances, of the performance.

I use the terms performative or performative language in the context of J.L. Austin's How to Do Things with Words and Judith Butler's application of that concept in gender studies. Austin's most basic definition of the performative is that 'the issuing of the utterance [constitutes] the performing of an action.11 For both philosophers, as well as Jacques Derrida, the success of performative language is contingent not upon the intention of the speaker but upon the apposite circumstances in which the performative is spoken. As Austin explains it, "it is always necessary that the circumstances in which the words are uttered should be in some way, or ways, appropriate, and it is very commonly necessary that either the speaker himself or other persons should also perform certain other actions, whether "physical" or "mental" actions or even acts of uttering further words. ${ }^{12}$ In using this theoretical framework, I will focus not only on performative language itself, but also on the circumstances in which that language (or any language) is uttered as well as the action that, as Austin notes, accompanies that language (performative or otherwise).

I would be remiss not to acknowledge that evoking the terms performative or performative language in relation to drama is doubly problematic. First, performance studies typically use performative to signify the adjectival form of performance. In my analysis of The Spanish Tragedy I do consider the play as a performed work, but I also explore how performance choices contribute to a sense that Kyd's play is 'performative' in the philosophical, linguistic sense. Second, Austin famously dismisses the application of his theory to drama: 
a performative utterance will, for example, be in a peculiar way hollow or void if said by an actor on the stage, or if introduced in a poem, or spoken in soliloquy. This applies in a similar manner to any and every utterance - a sea-change in special circumstances. Language in such circumstances is in special ways intelligibly — used not seriously, but in ways parasitic upon its normal use ways which fall under the doctrine of the etiolations of language. All this we are excluding from consideration. Our performative utterances, felicitous or not, are to be understood as issued in ordinary circumstances. ${ }^{13}$

While Derrida deconstructs the notion of 'ordinary circumstances' and contends that no distinction exists between ordinary and 'peculiar' circumstances, I believe his particular solution to the problem conflicts with my own argument that specific circumstances, or contexts, are essential to analyze language and action. ${ }^{14}$ Instead, I agree with W.B. Worthen that conventions within the theatre function to make the spoken words performative: 'As a citational practice, theatre — like all signifying performance — is engaged not so much in citing texts as in reiterating its own regimes of performances. Plays become meaningful in the theatre through the disciplined application of conventionalized practices - acting, directing, scenography — that transform writing into something with performative force: performance behavior.' 15 In The Spanish Tragedy, these theatrical conventions will prove essential to understanding Hieronimo's playlet. ${ }^{16}$

The early modern concept of theatrum mundi further renders the theory of the performative applicable to Renaissance drama since the close relationship between theatre and life is a reoccurring theme throughout the period. ${ }^{17}$ As Anne Barton argues in Shakespeare and the Idea of the Play, theatrum mundi is especially applicable to The Spanish Tragedy and its play-within-aplay structure (and with Soliman and Perseda, play-within-a-play-within-aplay): 'Revenge and Don Andrea watch a play within a play, unconscious of the fact that they themselves represent, for that theatre audience which they cannot see, simply the first in a series of three illusions receding into depth.' ${ }^{18}$ While production choice will dictate how 'unconscious' Revenge and Don Andrea are, these levels of illusions blur which parts of the performance are reality and which are theatre.

These vague boundaries between theatre and reality are one primary way in which Kyd explores the circumstances of his play's action. In addition to its multiple levels of illusions, The Spanish Tragedy is well suited for considering the relationship between language and action since Kyd repeatedly stresses 
setting and the expected language or action within that setting. By setting, I do not mean Spain; Kyd's sense of Spain is vague at best. I refer instead to the specific physical places where action transpires (among them, the bower and the royal Spanish court). When Lorenzo and Balthazar hang Horatio in the bower, a 'place ... made for pleasure not for death' (2.5.12), they change both the typical use of the bower - its usual circumstances - as well as the typical place for a hanging. A hanging would normally occur on the scaffold after Hieronimo, the knight marshal, pronounces a sentence of death; we see the proper circumstances at work in 3.6 when Hieronimo proclaims on the scaffold, 'God forbid / A fault so foul should scape unpunished! / Dispatch, and see this execution done' (99-101). In situating a hanging in a different setting, a setting in which we assume 'pleasure' and not death, Lorenzo and Balthazar effectively appropriate Hieronimo's performative power as knight marshal and justice to make a death sentence.

Both Austin and Butler emphasize a judge's unique performative power; in speaking a ruling, a judge effects the action of that ruling. For instance, when a judge says, 'Your motion is granted', this spoken ruling achieves the action of granting the motion. The circumstances surrounding the authority of a justice and his position uniquely imbue his words with performative power; in the words of Judith Butler: it is through the invocation of convention that the speech act of the judge derives its binding power, that binding power is to be found neither in the subject of the judge nor in his will, but in the citational legacy by which a contemporary "act" emerges in the context of a chain of binding conventions. ${ }^{19}$ The circumstances, conventions, or context matter most, not the individual's intention. Hieronimo, as knight marshal, speaks within the same citational legacy. When Hieronimo announces to the hangman to 'see this execution done' (101), he makes a binding ruling; his position as knight marshal renders his language, in Austin's words, 'felicitous'. ${ }^{20}$

Kyd effectively manipulates the circumstances and conventions of language and action, a manipulation that separates both language and action from their 'citational legacy' and removes Hieronimo from his usual legal power. Moving a hanging from a scaffold to Hieronimo's garden changes the circumstances and consequently removes the action from a judge's (specifically Hieronimo's) spoken and enacted power. ${ }^{21}$ Hieronimo even initially believes he will be the accused for the murder - 'And in my bower, to lay the guilt on me?' (2.5.11) - a statement that indicates he may lose his usual performative power to determine the guilty party. ${ }^{22}$ In manipulating what 
Sharon O'Dair so aptly calls 'arenas of performativity', ${ }^{23}$ therefore, Kyd erodes Hieronimo's power of language and action throughout The Spanish Tragedy. As I noted earlier, he can still effect some justice later in the play in 3.6 by declaring Pedringano guilty and calling for his execution, but Lorenzo and Balthazar effectively usurp his performative power as a judge by hanging Horatio. (Even within 3.6, however, Hieronimo is incapable of meting out justice on Lorenzo, who had actually solicited Pedringano to murder Serberine.) Consequently, Hieronimo uses Soliman and Perseda to signify the final, broken meaning of language and action. Just as the bower transforms from a place of love to a place of death, so the performance of Soliman and Perseda transforms the royal court from a place of proper justice (as we see earlier in the play) to a place of the perverted justice of private revenge. In staging this deadly playlet, Hieronimo destroys the power of the sovereign to enact justice within his own court. If we consider the way in which Kyd manipulates 'the authoritative practices relevant to a given arena of performativity', ${ }^{24}$ we can better understand why precisely Hieronimo locates his revenge - or, more appropriately, his justice - in the unusual, unordinary circumstances of a play at the royal court.

Prior to Lorenzo and Balthazar's murderous reversal of the bower's purpose from life to death, Kyd stresses the typical function of both language and action. In the play's opening act, language functions performatively within the Spanish royal court. The General's description of the recent victory of the Spanish over the Portuguese, for instance, creates the action of the battle for the court audience and works within a larger oral tradition of battle tales within epics (with The Iliad as just one example among many). The speech is particularly notable not just for the way in which the General vividly evokes the 'sounding trumpets, drums and fifes' and the 'dreadful clamours to the sky' (1.2.28-9), but also the way in which the speech shifts from past tense 'I brought a squadron of our readiest shot' $(35)$ — to present: 'Thick storms of bullets rain like winter's hail, / And shivered lances dark the troubled air' (53-4). Dead bodies fall to the ground with his words: 'On every side drop captains to the ground' (57). While he delivers the speech from the comfort of the Spanish court, he speaks as if the bloody carnage transpires in front of his audience: 'Here falls a body scindered from his head / There legs and arms lie bleeding on the grass' (59-60). Kyd exploits the performative oral tradition: to speak the speech is to create the action for the court audience (and the playhouse audience as well). In contrast to Soliman and Perseda, no members of the audience are harmed in the General's delivery of the speech, 
despite its violent language; the speech instead functions in an epic mode to create a vision of the battle, a tableau of action.

The proper performative power of language in this circumstance at court precedes a demonstration of the proper functioning of justice. Following the General's description of the battle, a stage direction specifies that Balthazar should enter between his captors, Lorenzo and Horatio: 'The Army enters, Balthazar between LORENZO and HORATIO, captive' (109 sd). If the stage direction were not there, however, the physical location of Balthazar between Lorenzo and Horatio would be evident in their linguistic (albeit not performative) sparring. In an exchange rife with 'negation and antithesis', ${ }^{25}$ Lorenzo and Horatio convey physical conflict with their words, after the King asks who deserves the title of conqueror:

LORENZO To me, my liege.

HORATIO

To me, my sovereign.

LORENZO This hand first took his courser by the reins.

HORATIO But first my lance did put him from his horse.

LORENZO I seiz'd his weapons and enjoy'd it first.

HORATiO But first I forc'd him lay his weapons down. (154-8)

Just as each holds an arm of Balthazar, so each holds an arm (or at least some feet) of the first line of this passage. The back-and-forth exchange that follows, in which Horatio counters Lorenzo's claims, is visually paralleled by back-and-forth pulling of the physical body of Balthazar. ${ }^{26}$ Simon Palfrey and Tiffany Stern's work on cues and parts in the early modern English playhouse helps to illuminate how the words themselves would have indicated to the actors these back-and-forth actions, as well as the counterclaims of Lorenzo and Horatio. ${ }^{27}$ If the actor playing Horatio receives a four-word cue, then he would receive 'To me, my liege', to which he counters with the nearly identical 'To me, my sovereign'. His role as equal supplicant is evident in the line's structure. After 'To me, my sovereign', Horatio's part includes the repeated phrase 'But first' at the beginning of his subsequent two lines. The repetition emphasizes his counters to each of Lorenzo's claims for his own triumph in battle. The second 'But first' is also in response to the cue, 'enjoy'd it first'. While performative language is not at work here, the circumstances in which the language is spoken and the action that transpires are essential, just as they are in performative language's success. The playhouse actors, as well as the theatrical audience, would understand that Lorenzo and Horatio are 
both making equal, balanced claims to their sovereign at the royal court. The language further conveys the actions that each performed on the battlefield; language mirrors the action of conflict over, as well as capture of, Balthazar.

Balthazar's description of his capture continues the linguistic and physical conflict:

To him in courtesy, to this perforce:

He spake me fair, this other gave me strokes:

He promis'd life, this other threaten'd death:

He wan my love, this other conquer'd me:

And truth to say I yield myself to both.

Balthazar addresses his captors in the same order (Lorenzo, then Horatio) as the two kept in their exchange. Jonas Barish argues, 'His final line, surprisingly, collapses the vivid contrast back into a noncommittal unity.' ${ }^{28}$ While the final line is 'noncommittal' in the sense that no one person is given the dominant claim, I disagree that it is particularly surprising. As both Lorenzo and Horatio share a line to start their response to the King and follow with four opposing lines of text, so Balthazar's speech mirrors that organization with four opposing lines of text (with the opposition further mirrored within the lines themselves) and a concluding line in which the two share the claim. Furthermore, Balthazar ends with a performative yielding to both figures; in saying 'I yield myself to both', he in effect performs the action of yielding himself to both claims. Given the circumstances at court in which both Lorenzo and Horatio claim Balthazar, and appeal those claims to the Spanish king, the language and action accurately reflect those circumstances.

Within the same scene, Hieronimo's words hold power within the Spanish court setting. In appealing for his son's rights, Hieronimo implores the King,

But that I know your grace for just and wise,

And might seem partial in this difference,

Enforced by nature and by law of arms,

My tongue should plead for young Horatio's right.

$(166-9)$

In his appeal, Hieronimo refers to the citational legacy of his words as knight marshal, 'Enforced by nature and by law of arms'. He is not merely a father pleading on behalf of his son; he is a knight marshal backed 'by nature and by law of arms'. In contrast to what happens later in the play, the King acknowledges Hieronimo's appeal, addressing him specifically as 'Marshal', and promises his claim will not be denied: 'Content thee, Marshal, thou shalt 
have no wrong, / And for thy sake thy son shall want no right' (173-4). Like a judge making a ruling, Hieronimo's words can effect action at the royal court, inciting the King to make a fair ruling. In making a ruling, the King himself exercises his performative power as sovereign to mete out justice. In contrast to the instability of language and action later in the play, the King notably gives a balanced ruling within the 'arena of performativity' of the royal court. As James T. Henke notes, the King in this scene appears 'generously mindful of his obligations to his subjects, painstakingly judicious, and politically astute. ${ }^{29} \mathrm{He}$ properly performs his role as sovereign at the Spanish court.

The power of Hieronimo's own language within the court is also seen later in act 1 in a theatrical context when Hieronimo presents a dumb show before the King and the Portuguese ambassador. The action takes place before any words are spoken: 'Enter HIERONIMO with a Drum, three Knights, each his scutcheon: then he fetches three Kings, they take their crowns and them captive' (1.4.137 sd). The King says the action of the dumb show is pleasing, but he cannot understand the meaning: 'Hieronimo, this masque contents mine eye, / Although I sound not well the mystery' (138-9). Before Hieronimo explains, the King only processes the action as an appealing visual. Hieronimo's descriptions create meaning for the King by identifying each English hero and his accomplishments. In contrast to Hieronimo's later playlet, the King and the Portuguese ambassador understand the action of the dumb show after Hieronimo explains it.

After establishing this balanced relationship between language and action, particularly in relation to Hieronimo, Kyd shatters this world by transforming the 'arena' of the bower in 2.4. Kyd first underscores the connection between the bower and life and fertility through Bel-imperia and Horatio's evocative linguistic coupling within the setting:

HORATIO Then thus begin our wars: put forth thy hand,

That it may combat with my ruder hand.

BEL-IMPERIA Set forth thy hand to try the push of mine.

HORATIO But first my looks shall combat against thine.

BEL-IMPERIA Then ward thyself, I dart this kiss at thee.

HORATio Thus I retort the dart thou threw'st at me.

BEL-IMPERIA Nay then, to gain the glory of the field,

My twining arms shall yoke and make thee yield. 
HORATIO Nay then, my arms are large and strong withal:

Thus elms by vines are compass'd till they fall.

While the exchange is devoid of stage directions, the action of physical entwining is intertwined with the lovers' language. Horatio rhymes hand with hand to imply how his hand (albeit ruder) equally matches Belimperia's. They complete each other's rhyming couplets, 'mine/thine' and 'thee/me', to evoke their mutual experience of pleasure. When Bel-imperia tries to dominate, 'to gain the glory of the field', Horatio appropriates her opening words, 'Nay then' and indicates how he has overmatched her in language as well as physical strength: 'Thus elms by vines are compass'd till they fall'. While it reads as a romantic exchange, the words also hint at the upcoming violence.

Following the intimation of violence, Kyd effectively manipulates circumstances and changes the proper relationship between language and action. As I have already noted, it is essential that Lorenzo and Balthazar hang Horatio within the bower since this action appropriates Hieronimo's power to enact justice and declare when the guilty should be hanged. ${ }^{30}$ Lorenzo speaks of Horatio that 'Although his life were still ambitious proud, / Yet is he at the highest now he is dead' (60-1). Lorenzo, as a noble, certainly feels that Horatio has overstepped his class in wooing Bel-imperia. As an execution method, hanging was typically reserved for the lower classes; ${ }^{31}$ Lorenzo, then, comments on Horatio's class in his 'punishment' when he appropriates a judge's or knight marshal's ability to sentence a lower-class criminal. ${ }^{32}$ Horatio is not a criminal, however, and the 'sacred bower' (2.5.27) is not the scaffold. The language of execution and the action of hanging transform the bower's typical usage. 33

By re-contextualizing hanging, and appropriating Hieronimo's power to effect justice, Lorenzo and Balthazar erode Hieronimo's linguistic power as knight marshal. Whereas Hieronimo has the King's ear in the earlier court scenes, his language fails to achieve the same effect in later scenes. At the beginning of 3.12, Hieronimo assumes he still holds sway at court: 'Now, sir, perhaps I come and see the King; / The King sees me, and fain would hear my suit' (1-2) and 'Away, Hieronimo, to him be gone! / He'll do thee justice for Horatio's death' (12-13). When he entreats the King, however, his language fails. While Lorenzo initially seems to prevent Hieronimo from reaching the King — 'Back! Seest thou not the King is busy?' (28) — Hieronimo's pleas for justice strangely do not affect the King, regardless of whether or 
not Lorenzo physically prevents Hieronimo from reaching him. The King recognizes who calls out for justice, acknowledging him by name:

hieronimo Justice, O justice, justice, gentle King!

KING Who is that? Hieronimo?

hieronimo Justice, O justice! O my son, my son,

My son, whom naught can ransom or redeem! (63-6).

Even if Hieronimo's words degenerate into madness, the frequent repetition of the word 'justice' remains unheeded. Hieronimo himself seems to acknowledge this new lack of power when he exclaims that he will 'surrender up [his] marshalship' (76). After all, his words and actions no longer achieve what they once did in the court.

Denied his usual performative power in the court setting, where saying 'justice' would effect justice, Hieronimo uses the playlet of Soliman and Perseda to destroy language and action's power, particularly that of his sovereign. To do so, Hieronimo manipulates the circumstances of the theatre in much the same way as Lorenzo and Balthazar change the typical circumstances of a hanging. First, Hieronimo's choice to use multiple languages in Soliman and Perseda breaks the theatrical convention that the audience will understand what happens on the stage; as is clear from the royal spectators' comments, the court audience for Hieronimo's playlet never understands what happens even though Hieronimo provides them the plot at 4.3.6. Second, although actors in the Elizabethan playhouse only received limited lines from other parts, they still could understand what those actors were saying since those parts were usually in English (or at least understandable when spoken); the court performers cannot do so here, given Hieronimo's choice of a multitude of languages. Third, the playlet ruptures the relationship between theatre and reality when the seemingly pretended stabbing of the theatrical performance results in the deaths of the playlet's actors.

In contrast to the dumb show that became comprehensible through Hieronimo's language, the language in Soliman and Perseda is ineffective at conveying meaning. Balthazar's first speech, for instance, is rife with details that cannot be successfully conveyed to the audience since he performs the part in Latin. In the English translation, his speech reads:

Bashaw, that Rhodes is ours, yield heavens the honour,

And holy Mahomet, our sacred prophet:

And be thou grac'd with every excellence 
That Soliman can give, or thou desire.

But thy desert in conquering Rhodes is less

Than in reserving this fair Christian nymph,

Perseda, blissful lamp of excellence,

Whose eyes compel, like powerful adamant,

That warlike heart of Soliman to wait.

The specific phrases 'our sacred prophet', 'thy desert in conquering Rhodes', 'this fair Christian nymph', 'blissful lamp of excellence', 'powerful adamant', and 'warlike heart' would all be untranslatable to the audience by means of action. When the King observes,

See, Viceroy, that is Balthazar your son

That represents the emperor Soliman.

How well he acts his amorous passion!

he understands Balthazar acts 'amorous passion', but he does not seemingly understand any other details. ${ }^{34}$ The King says nothing, for instance, about Balthazar/Soliman also celebrating a military victory, the seizing of Rhodes. The King is in a position similar to his own position during Hieronimo's dumb show; he needs someone to interpret for him. But, as we shall see, even Hieronimo's interpretation at this point in the play proves ineffective. Moreover, while the playhouse audience would know the general plot from Hieronimo's earlier explanation in 4.1, the multitude of languages may have still proven challenging to the early modern English audience. The general plot is known, but what the performers are saying is less clear.

The characters performing within the playlet would be as confused as their court audience. Given the Elizabethan practice of role distribution, 35 Bel-imperia, Balthazar, and Lorenzo would not have understood each other since Hieronimo provides their separate roles in different languages:

And here, my lords are several abstracts drawn,

For each of you to note your parts,

And act it as occasion's offer'd you.

Since their roles would only contain their own lines and a two- to five-word cue from other parts, the details from their fellow performers would have been lost, in contrast to the professional actors' earlier usage of cues in playing Lorenzo's and Horatio's parts. As aristocrats and nonprofessional actors, Bel-imperia, Balthazar, and Lorenzo would not be as adept at language 
intonations as professional actors would. (Of course, the professional actors here must feign the aristocrats' confusion when they play the characters in this scene.) In other words, when the character Balthazar says, 'Ah, Bashaw, here is love between Erasto / And fair Perseda, sovereign of my soul' (4.4.39-40), he may not have understood that Lorenzo was 'Thrice happy' that Perseda lives and that 'Rhodes' loss is nothing to Erasto's joy: / Sith his Perseda lives, his life survives' (37-8) since Lorenzo speaks in Italian. He may glean some meaning, just as the King of Spain does, but no action or gestures could convey poetic details spoken in another language, details like 'Sith his Perseda lives, his life survives'.

With the actors also unable to interpret meaning through action, the meaning of action itself falls apart. In the 'independent and dangerous life' of actions in Soliman and Perseda, gestures take on meaning they do not have in a regular theatrical context. ${ }^{36}$ While the audience, both in the royal court and in the playhouse, as well as the characters of Balthazar and Lorenzo, assume that the gesture of stabbing means that the actors are only pretending to be dead, 'pretend' stabbing causes 'real death': 'to kill in fact the victims whose "killing" he might only have represented in theater'. ${ }^{37}$ By crossing the boundary into reality (the reality of the court in The Spanish Tragedy), breaking down theatrical conventions, and 'draw[ing] attention to the nebulous nature of the boundary that separates spectators from the spectacle', ${ }^{38}$ Hieronimo destroys the audience's familiar understanding of the relationship between action in the theatre and action in 'real life'. Without a definable relationship between language and action, language can no longer effect action.

After the playlet concludes, Hieronimo provides a long explanation to the royal court of his motivation (73-152). Despite the wealth of detail, the confused members of the court demand that Hieronimo name his accomplices and explain why their children are dead. Critics have attempted to explain this illogical progression from Hieronimo's explanation to the royal court's confusion by suggesting either the text is corrupt or the court is so distraught that none of them fully processes what Hieronimo says. ${ }^{39}$ I propose, in contrast, that the court's confusion reflects the consequences of Hieronimo's manipulation of the circumstances necessary for the ability of language, performative or otherwise, to function properly. When Hieronimo shows Horatio's body, he says, 'Behold the reason urging me to this: [Shows his dead son.] / See here my show, look on this spectacle' (88-9, emphasis added). His words coincide with the action of revealing Horatio's body, and he entreats 
the court to look at his son. Like Lorenzo and Balthazar before him, however, he has moved an execution outside of the logical, state-sanctioned context of the scaffold; he has rendered the logic behind his justice incomprehensible by placing a hanged body within the illogical setting of both the royal court and a theatrical performance. The King's response, 'Why hast thou done this undeserving deed?' (165), reflects the fact that this transformed context has made Hieronimo's language and action unintelligible to the court. None of the royals ever acknowledges Horatio or his murder, even though his corpse would conceivably be rotting by this point in the action. Dismissing the futility of further explanation, since language and action together have become meaningless, Hieronimo scoffs, 'O good words!' (168).

Following his ineffective explanation, Hieronimo enacts the final meaninglessness of language and action by violently severing his own tongue. Before he bites out his tongue, Hieronimo tries to keep silent (180-1), but the King threatens torture: 'Traitor as thou art, I'll make thee tell' (184). The King tries to force words through violent action; he attempts to reestablish his power of performative language within the 'arena of performativity' of the court. ${ }^{40}$ Hieronimo instead emphasizes the final destruction of that relationship by biting out his tongue. After receiving a pen to write the names of his accomplices, Hieronimo gestures to the court for a knife: 'Then he makes signs for a knife to mend his pen' (198 sd). The court correctly interprets that he wants a knife, but they continue to misunderstand the true meaning behind the action: 'Oh, he would have a knife to mend his pen' (199). Instead of mending his pen to communicate, Hieronimo uses the penknife to stab the Duke of Castile and himself, further destabilizing the action of stabbing, which has already lost its theatrical meaning, and killing one of the playlet's spectators. While the death of the Duke of Castile has proven confusing for critics (since the Duke of Castile is blameless for Horatio's death), ${ }^{41}$ his death also reflects Hieronimo's transformation of circumstances and destruction of language and action's effectiveness. The Duke of Castile is not only a spectator but also the King's brother and subject throughout the play to the King's power. Without any heirs of his own, the King uses his brother's heir, Bel-imperia, to secure the Spanish line. In the negotiations over the marriage between Bel-imperia and Balthazar, the King commands Castile, 'Go, brother, it is the Duke of Castile's cause; / Salute the Viceroy in our name' (3.14.1-2, emphasis added). In employing a penknife as a weapon, Hieronimo also uses 'an instrument of written words', ${ }^{42}$ or written language, to cause death. Hieronimo's hand goes idle, 'Nunc iners cadat manus', as he 
says in the 1602 additions to the play (Fifth Addition 47), because he also does not need to use written words for language. He has no further use for language of any kind.

As I have established in this essay, context is emphasized throughout The Spanish Tragedy. Hieronimo's violent manipulation of both the theatrical and court contexts, his ruination of language, action, and justice, is akin to Lorenzo and Balthazar's appropriation of the means of justice for personal revenge. As Lukas Erne proposes, Hieronimo's playlet also signals the fact that man can effect change in society, apart from God. In manipulating the theatrical context, Hieronimo not only re-appropriates his own ability to effect justice as knight marshal, demonstrated in particular by a justice's power of performative language, but also assumes a godlike position: 'Hieronimo shows that the idea of the theatrum mundi can take on a radically different meaning. The traditional topos asserts that we are all subject to God's dramaturgy, but the Spanish tragedy, that is, the wiping out of an entire royal line, is brought about by human dramaturgy. ${ }^{3} 3$ Hieronimo's 'human dramaturgy' destroys the relationship between theatre and reality, and, in doing so, destroys the relationship between language and action. Through his playlet, therefore, Hieronimo assumes a God-like position, and, as Sandy Petrey points out, 'divine beings are totally incapable of performative speech, which is accomplished solely by the protocols of organizing human communities. God stands outside those communities, conventions are radically inapplicable ... [and] the norms of social interaction fail to reach heaven. ${ }^{34}$ Hieronimo ultimately separates himself from human conventions by separating his playlet from typical theatrical circumstances. Kyd's unique investment in context within The Spanish Tragedy, his transformation of circumstances and manipulation of 'arenas of performativity', radically alters what both language and action mean and accomplish throughout his play, and no doubt explains the play's popularity onstage and in print.

\section{Notes}

I wish to thank everyone who has read this article in its various stages. My thanks in particular go to Sharon O'Dair, Jennifer Drouin, Heather White, Jolynn AmrineGoertz, Erin Chandler, Nicholas Helms, Natalie Hopper, Catherine Merritt, Allison Schuver, Adam Wear, Daniel Ferretti, and the anonymous readers from Early Theatre. I am grateful for all of the useful feedback. 
1 Emma Smith, 'The Spanish Tragedy, Not Shakespeare: Elizabethan and Jacobean Popular Theatre', University of Oxford, 4 September 2010, iTunes U.

2 Lukas Erne provides the most extensive modern performance history of the play in his chapter 'The Spanish Tragedy: Additions, Adaptations, Modern Stage History' in Beyond The Spanish Tragedy: A Study of the Works of Thomas Kyd (New York, 2001), 119-45.

3 Three notable studies on the function of language within The Spanish Tragedy include James R. Siemon, 'Dialogical Formalism: Word, Object, and Action in The Spanish Tragedy', Medieval and Renaissance Drama in England 5 (1991), 87-115 (which gives a Bakhtinian reading to The Spanish Tragedy); Jonas Barish, 'The Spanish Tragedy, or The Pleasures and Perils of Rhetoric', John Russell Brown and Bernard Harris (eds), Elizabethan Theatre (London, 1966), 59-85; and Carol McGinnis Kay, 'Deception through Words: A Reading of The Spanish Tragedy,' Studies in Philology 74.1 (1977), 20-38. Among the studies on the play's theatricalism and spectacle include those by Eleanor Tweedie, "'Action is Eloquence”: The Staging of Thomas Kyd's Spanish Tragedy', Studies in English Literature, 1500-1900 16.2 (1976), 223-39; William N. West, "But this will be mere confusion": Real and Represented Confusions on the Elizabethan Stage', Theatre Journal 60 (2008), 217-33; Molly Smith, 'The Theater and the Scaffold: Death as Spectacle in The Spanish Tragedy', Studies in English Literature, 1500-1900 32.2 (1992), 217-32; Lorna Hutson, 'Rethinking the "Spectacle of the Scaffold": Juridical Epistemologies and English Revenge Tragedy', Representations 89 (2005), 30-58; and Barry B. Adams, 'The Audiences of The Spanish Tragedy', The Journal of English and Germanic Philology 68.2 (1969), 221-36.

4 All references to The Spanish Tragedy come from Thomas Kyd, The Spanish Tragedy, ed. Philip Edwards (Cambridge, 1959).

5 Reference from The Geneva Bible, the facsimile of the 1560 edition. Kyd would probably have been most familiar with this English version of the Bible.

6 Arthur Freeman, Thomas Kyd: Facts and Problems (Oxford, 1967), 65.

7 Edwards, in the Revels introduction, and Murray, Thomas Kyd, both disagree with the general consensus that the playlet was performed in multiple languages. They are part of a small minority, as Janette Dillon addresses in 'The Spanish Tragedy and Staging Languages in Renaissance Drama,' Research Opportunities in Renaissance Drama 34 (1995), 14.

8 William N. West, “'But this will be mere confusion”,' 219. Carla Mazzio, The Inarticulate Renaissance: Language Trouble in an Age of Eloquence (Philadelphia, 2009), also acknowledges the playlet's confusion.

9 Katharine Eisaman Maus also considers the effect of the playlet in Inwardness and Theater in the English Renaissance (Chicago, 1995), 55-71. Her class-based study of 
the playlet suggests that while Hieronimo's playlet fails to achieve 'fellow feeling' between the court and himself, it does 'provid[e] the basis of an effective defiance' (70).

10 Dillon, 'The Spanish Tragedy and Staging Languages', also contends that the multiple languages of the playlet have a specific theatrical function. She argues not from the performative angle, but from the perspective that the audience's incomprehensibility would signal language's breakdown in relation to sound.

11 J.L. Austin, How to Do Things with Words, 2nd edn (Cambridge, 1975), 6. DOI: http://dx.doi.org/10.1093/acprof:oso/9780198245537.001.0001

12 Ibid, 8-9 (emphasis in original). Jacques Derrida also articulates the necessity of circumstances in 'Signature Event Context', in which he explains the citational legacy of performatives and their iterability. See Jacques Derrida, 'Signature Event Context', trans. Samuel Weber and Jeffrey Mehlman, in Gerald Graff (ed.), Limited Inc (Evanston, 1988), 1-23. Butler's insistence on the ability of acts to construct gender and sex shifts the focus from the body itself and toward the power of context, conventions, and Butler's oft-used term, 'norms'.

13 Austin, How to Do Things with Words, 22 (emphasis in original).

14 Derrida, 'Signature Event Context': 'isn't it true that what Austin excludes as anomaly, exception, "non-serious", citation (on stage, in a poem, or a soliloquy) is the determined modification of a general citationality — or rather, a general iterability - without which there would not even be a 'successful' performative?' (17).

15 W.B. Worthen, Shakespeare and the Force of Modern Performance (New York, 2003), 9. DOI: http://dx.doi.org/10.1017/CBO9780511484087

16 Shoshana Felman's argument in The Literary Speech Act: Don Juan with J.L. Austin, or Seduction in Two Languages (Ithaca, 1983), also provides an elegant solution to disregarding Austin's distinction. Felman contends that Austin's words themselves in How to Do Things with Words should be considered speech acts. Austin dismisses jokes, just as he dismisses literature, but, Felman contends, he also uses jokes to prove his theory.

17 Stephen Greenblatt explores this notion in much of Renaissance Self-Fashioning (Chicago, 1980; reprint, Chicago, 2005), particularly in his study of Sir Thomas More. Other critics who explore theatrum mundi in depth include Kent T. van den Berg, Playhouse and Cosmos: Shakespearean Theater as Metaphor (Newark, 1985); Lynda Gregorian Christian, Theatrum Mundi: The History of an Idea (New York, 1987); and Louis Montrose, The Purpose of Playing: Shakespeare and the Cultural Politics of the Elizabethan Theatre (Chicago, 1996).

18 Anne [Righter] Barton, Shakespeare and the Idea of the Play (London, 1962), 81. 
19 Judith Butler, Bodies That Matter: On the Discursive Limits of 'Sex' (New York, 1993), 225.

20 Austin, How to Do Things with Words, 22.

21 In The Inarticulate Renaissance, Mazzio also acknowledges the importance of Hieronimo's legal position in regards to the playlet, but more so from the problems within the contemporary early modern English legal community than from Hieronimo's legal position within the play: 'the problems that a polyglot and often "vncoherent" law could pose for legal advocates inform the play in ways that scholars have not yet recognized' (117).

22 I am grateful to an anonymous reader for pointing to this passage.

23 Sharon O'Dair, “Philosophy in a Gorilla Suit”: Do Shakespearians Perform or Just Perform-a-tive?', Shakespeare Survey 60 (2007), 150.

24 Ibid, 151.

25 Sheldon P. Zitner, 'The Spanish Tragedy and the Language of Performance', Elizabethan Theatre 11 (1990), 82.

26 Barish, 'The Spanish Tragedy, or the Pleasures and Perils of Rhetoric', 70.

27 Simon Palfrey and Tiffany Stern, Shakespeare in Parts (Oxford, 2007). DOI: http:// dx.doi.org/10.1093/acprof:oso/9780199272051.001.0001

28 Barish, 'The Spanish Tragedy, or the Pleasures and Perils of Rhetoric', 70.

29 James T. Henke, 'Politics and Politicians in The Spanish Tragedy', Studies in Philology 78.4 (1981), 354. Erne, Beyond The Spanish Tragedy, agrees: 'Kyd goes out of his way to stress that the King's treatment of Horatio is fair' (90). Henke effectively shows that the King actually makes balanced judgments. Furthermore, if the king were at fault then Hieronimo would have also killed him; Hamlet, after all, kills his own sovereign.

30 Smith, 'The Theater and the Scaffold', notes that 'No other play of the Renaissance stage dwells on the spectacle of hanging as Kyd's does' (217). It does so precisely because of Hieronimo's role as a justice.

31 Ibid, 'The Theater and the Scaffold', 230n.

32 Ibid, 222, focuses on the centrality of Horatio's hanged body within the play: 'Horatio's gruesome murder in the arbor remains the centerpiece; we come back to it again and again through Hieronimo's recounting of it, and as if to reiterate its centrality, the playwright exploits the value of the mutilated body as spectacle by holding Horatio's body up to view either literally or metaphorically several times in the course of the play'.

33 Isabella's violent destruction of the bower and her suicide in 4.2 further emphasizes the bower's transformed circumstances. In the famous painter scene of the 1602 additions, Isabella also highlights the importance of the bower as a setting of death: 
How? Be merry here, be merry here?

Is not this the place, and this the very tree,

Where my Horatio died, where he was murdered?

(Fourth Addition. 59-61)

34 Tweedie, "Action is Eloquence", 229.

35 Palfrey and Stern, Shakespeare in Parts and Tiffany Stern, Rehearsal from Shakespeare to Sheridan (Oxford, 2000). DOI: http://dx.doi.org/10.1093/acprof :oso/9780199229727.001.0001

36 Barish, 'The Spanish Tragedy, or the Pleasures and Perils of Rhetoric', 83.

37 Peter Sacks, 'Where Words Prevail Not: Grief, Revenge, and Language in Kyd and Shakespeare,' ELH 49.3 (1982), 583.

38 Smith, 'The Theater and the Scaffold', 228.

39 Arguments made, respectively, by Edwards in the Revels edition and Murray, Thomas Kyd.

40 Erne, Beyond The Spanish Tragedy, agrees: 'the King's power is destabilised not only by what is represented, but also by his lack of control over its exegesis' (98).

41 S.F. Johnson, 'The Spanish Tragedy, or Babylon Revisited,' Richard Hosley (ed.), Essays on Shakespeare and Elizabethan Drama in Honor of Hardin Craig (Columbia, 1962): 'His reasons, if any, for killing Castile are not even hinted at' (34).

42 Kay, 'Deception through Words', 37n.

43 Erne, Beyond The Spanish Tragedy, 102.

44 Sandy Petrey, Speech Acts and Literary Theory (New York, 1990), 63. 